\title{
BREEDING BIRD ABUNDANCE AND HABITAT ALONG THE DES LACS RIVER VALLEY, NORTH DAKOTA
}

ROBERT K. MURPHY, U.S. Fish and Wildlife Service, Des Lacs National Wildlife Refuge Complex, 8315 Hwy 8, Kenmare, ND 58746 (bob_murphy@fws.gov) and MARRIAH L. SONDREAL, College of Natural Resources, University of Wisconsin, Stevens Point, WI 54481 (current address: N8386 County Highway D, Belleville, WI 53508)

The Des Lacs River originates in se Saskatchewan and extends $100 \mathrm{~km}$ into nw North Dakota before joining the Souris River about $15 \mathrm{~km}$ nw of Minot (Figure 1). In the late 1800 s, just before settlement along the river by peoples of European descent, the valley of the "Riviere de Lacs" was mixedgrass prairie.? In 1878, Elliot Coues described the makeup of breeding birds along the Saskatchewan-North Dakota border, ${ }^{5}$ including the Des Lacs and Souris rivers. Bird habitat along the Des Lacs River valley has changed markedly since. Woodlands developed after extirpation of bison in the region during the 1870 s and, especially, after many decades of fire suppression following settlement. ${ }^{4,7}$ The prairie was converted to annually tilled croplands, except for a 0.5 to $2-\mathrm{km}$ wide band of prairie which still exists along the river. Nearly half of this extant prairie lies within the boundaries of Des Lacs National Wildlife Refuge (DLNWR), which encompasses the river valley just south of the Saskatchewan-North Dakota border

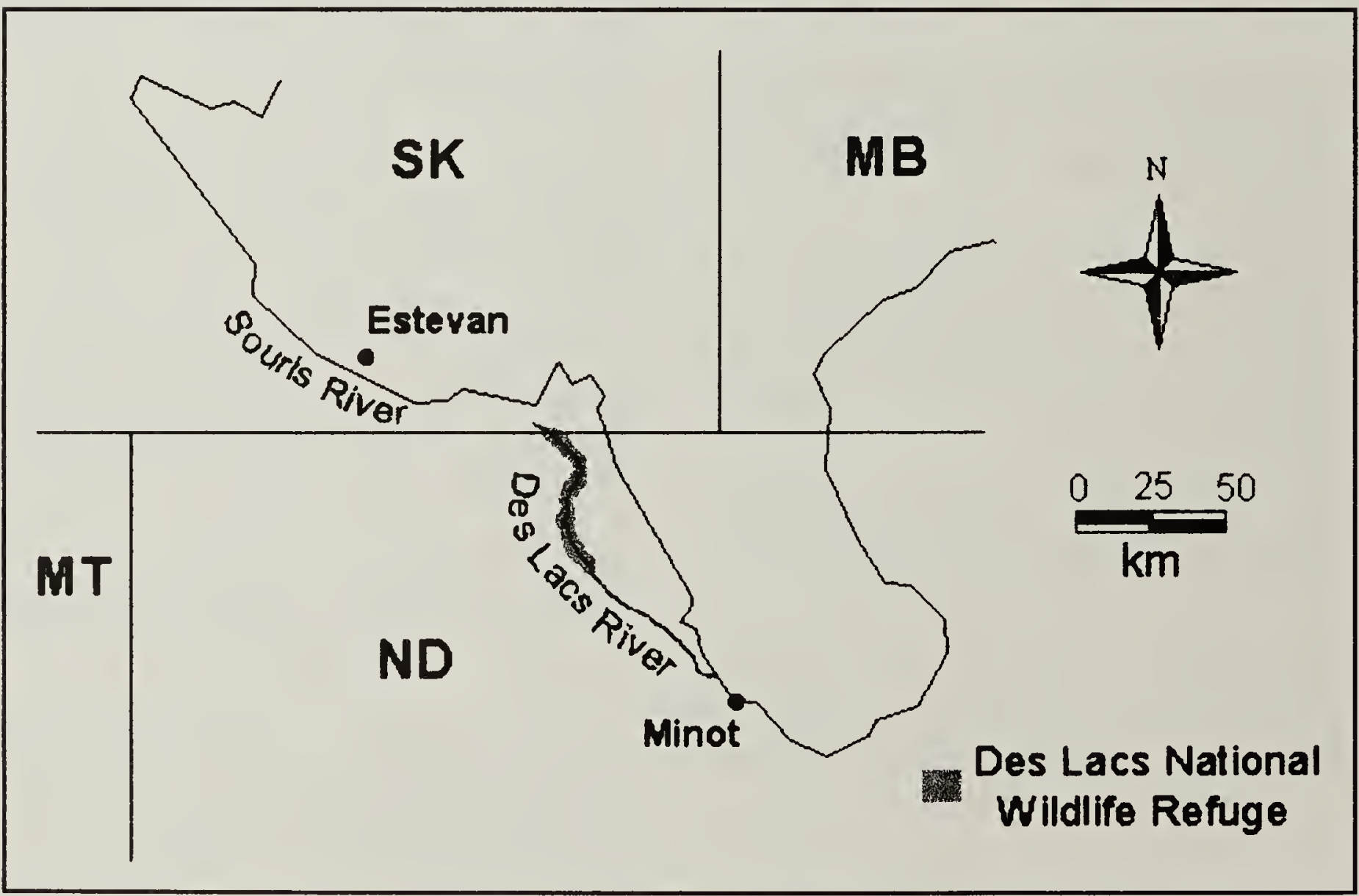

Figure 1. Location of Des Lacs National Wildlife Refuge along the Des Lacs River valley in nw North Dakota. 


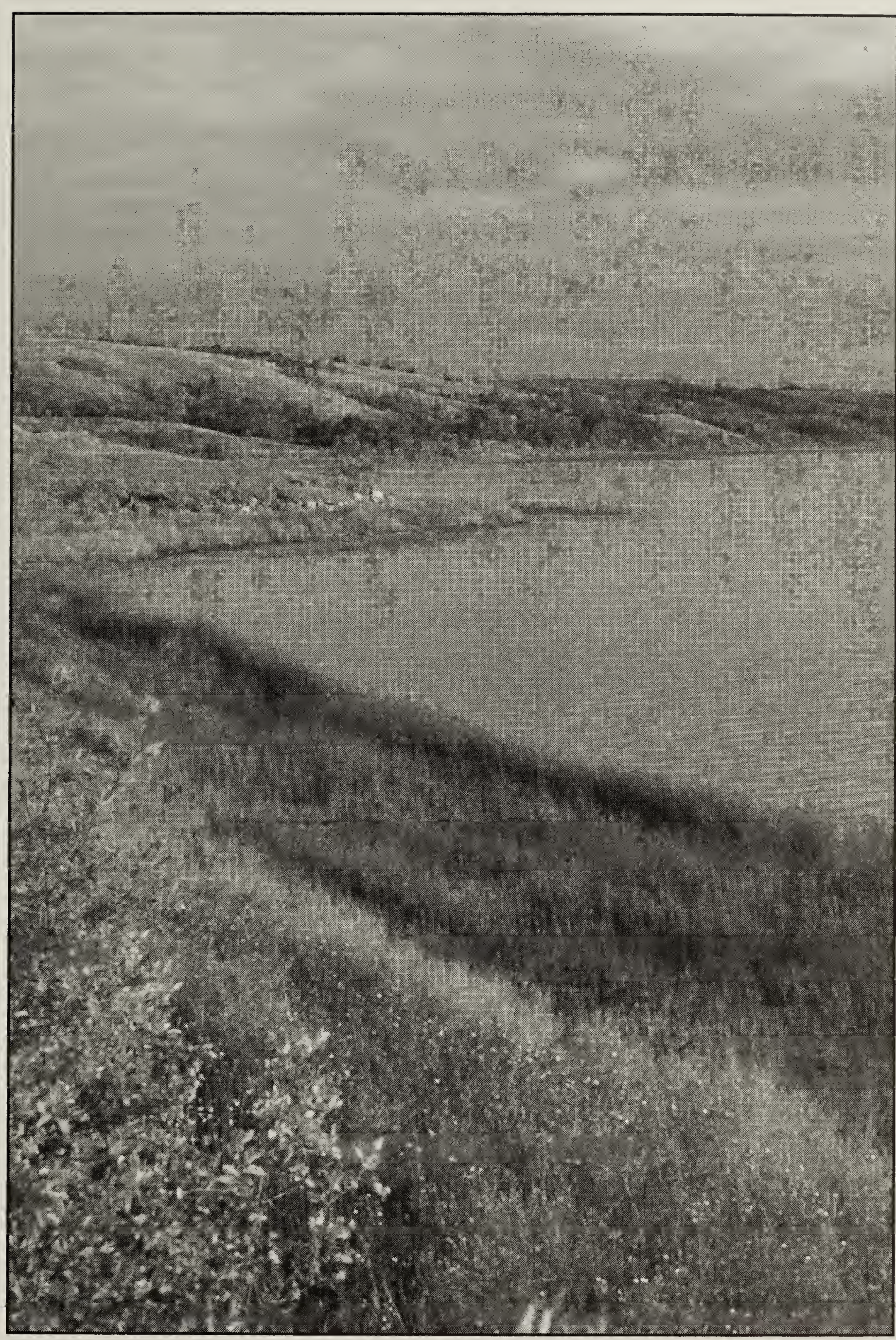

Figure 2. The Des Lacs River valley in late summer, south of the Saskatchewan-North Dakota border. 
(Figures 1 and 2). The refuge presents an opportunity for preserving native prairie and its associated bird life. No quantified description of contemporary breeding birds and their habitat associations exists for this major river valley, however. Our objective was to fill this information gap and help identify local opportunities and limitations for meeting habitat needs of bird species of regional and international conservation concern.

\section{Study Area and methods}

DLNWR encompasses the Des Lacs River valley in Burke and Ward counties in nw North Dakota, stretching south $42 \mathrm{~km}$ from se Saskatchewan. The valley of the Des Lacs River was created when glacial meltwater cut through a vast regional ground moraine known as the Drift Plain. ${ }^{3}$ Today the upland topography changes from the gently rolling Drift Plain to steep $\left(>15^{\circ}\right)$ slopes that descend 15 to $80 \mathrm{~m}$ to the river (elevation about $544 \mathrm{~m}$ ). The slopes are interrupted by wooded draws and coulees, which have intermittent streams that drain the adjacent Drift Plain. The narrow (1-3 km wide), 7913ha riverine refuge includes about 2025 ha of impounded open water and 280 ha of marsh and wet meadow bordered by roughly 5600 ha of upland habitats. Upland soils are mostly well-drained, level to steep loams formed in glacial till. The area climate is continental, with short summers and long cold winters; annual precipitation averages $45 \mathrm{~cm}$ (U.S. Fish and Wildlife Service [FWS], unpubl. refuge data). Our survey in 1994 followed a series of relatively dry years (1988-1993, average annual precipitation = $35 \mathrm{~cm}$ ), and the survey in 2001 occurred after many wet years (1994-2000, average annual precipitation $=51 \mathrm{~cm})$.

We identified five major upland habitats on the refuge: (1) woodland (351 ha): eastto north-facing slopes along the valley and adjacent coulee bottoms, with more than $50 \%$ tree canopy cover, primarily Green Ash (Fraxinus pennsylvanica) and American Elm (Ulmus americana); (2) woodland-prairie edge (roughly 1500 ha): east- to north-facing slopes along the valley and parts of adjacent Drift Plain, variably (5-50\%) wooded with trees and tall shrubs, mostly Green Ash and Chokecherry (Prunus virginiana); (3) prairie slope (roughly $750 \mathrm{ha}$ ): south- to west-facing slopes of the river valley, generally consisting of native prairie dominated by grasses and forbs especially needlegrasses (Stipa spp.), wheatgrasses (Agropyron spp.), Sideoats Grama (Bouteloua curtipendula), Little Bluestem (Schizachyrium scoparium), Big Bluestem (Andropogon gerardii), and members of the legume and aster families; (4) drift prairie (roughly $2250 \mathrm{ha}$ ): level to rolling $\left(<5^{\circ}\right)$ native prairie on the Drift Plain, dominated by a mix of Smooth Brome (Bromus inermis), Kentucky Bluegrass (Poa pratensis), Western Snowberry (Symphoricarpos occidentalis), and Silverberry (Elaeagnus commutata); (5) dense nesting cover (752 ha): cultivated tracts of Drift Plain that have been seeded to a mixture of introduced species of grasses and forbs to provide nesting cover mainly for ducks.

We used point counts ${ }^{8}$ to survey breeding birds throughout uplands at DLNWR from the end of May through June in 1994 and 2001. We used 30-m radius point count plots in woodland, and 75-m radius plots in other more open, habitats. Plots for woodland, prairie slope, and prairie-woodland edge were along 300 - to $1000-\mathrm{m}$ long transects that followed the mid-slope between the Drift Plain (above) and the river or bottoms of adjoining coulees (below). Plots on the Drift Plain were on transects that crossed through the approximate center of representative dense nesting cover and drift prairie habitats. We typically randomized our starting point on each transect and then spaced plot centers at least $200 \mathrm{~m}$ apart by pacing. We conducted surveys in 2001 in most of the same general areas used in 1994, although we seldom used any one plot in both years. Habitat of each plot was classified in the field as woodland, woodland-prairie edge, prairie slope, drift prairie, or dense nesting cover based on the 
dominant vegetation, slope, and aspect. We surveyed birds across all major upland habitats regardless of management history (for example, some areas had been prescribeburned the previous year, or were being grazed by livestock), although we excluded dense nesting cover areas that were being disked in preparation for reseeding.

We surveyed each plot once for eight minutes between 5:30 and 8:30 AM. We occasionally surveyed birds until 9:00 AM on unusually calm mornings, and did not conduct surveys during steady rain or strong ( $>25 \mathrm{kmph}$ ) winds. Each plot was entered slowly to note birds that might be disturbed by our approach. We recorded numbers of singing males of each species in each plot and excluded non-singing birds from our summaries except for obvious breeding pairs (e.g., a pair of adult sparrows carrying food and eliciting threat notes). For species that use aerial displays to attract mates and defend territories (e.g., Sprague's Pipit), we recorded a singing individual if its flight path crossed over the plot during our survey. Birds detected outside each plot but within the same respective habitat type also were recorded to help us build a list of infrequently encountered species. ${ }^{8}$ We generally considered a singing male to indicate a breeding pair, but calculated the abundance of Brown-headed Cowbird and Cedar Waxwing at each point by dividing the total number observed by two. ${ }^{12}$ For every species we calculated the average number of indicated pairs per point count plot in each habitat class for 1994 and 2001. We also plotted the percentage frequency of occurrence for common species (i.e., those with an average abundance of more than 0.1 indicated pairs/plot in at least one year), to look for large differences in species occurrence between study years.

\section{Results}

We recorded 72 species of breeding birds (475 and 247 plots surveyed in 1994 and 2001, respectively; Table 1). This total excludes shorebirds that nested in margins of seasonally flooded wetlands in the Drift Plain such as Wilson's Snipe and Wilson's Phalarope; seven species of upland-nesting ducks; four swallow species that foraged over prairie slope, drift prairie, and dense nesting cover habitats but nested elsewhere; and several non-breeding late migrant or vagrant species such as Tennessee Warbler or Western Wood Pewee.

Occurrences of several common breeding species differed between our survey years (Figure 3). Yellow Warbler occurred about twice as frequently on woodland plots in 2001 than in 1994. In woodland-prairie edge, Cedar Waxwing occurred twice as frequently in 2001 as in 1994, but Eastern Kingbird and Song Sparrow were nearly twice as frequent in 1994. Savannah Sparrow and Bobolink occurred $50-80 \%$ more frequently in drift prairie and dense nesting cover in 2001 than in 1994, and Savannah Sparrow also was more frequent in prairie slope in 2001. Claycolored Sparrow occurred 20-100\% more frequently in all habitats in 2001 compared to 1994.

The greatest number of species occurred in woodland-prairie edge and the fewest occurred in dense nesting cover (Table 1). Woodland-prairie edge also had the greatest number of common species, 14, compared to five to eight common species in other habitats (Figure 3). However, most species that were common in woodland-prairie edge also were common in other habitats.

\section{Woodland Species}

Least Flycatcher, House Wren, and Yellow Warbler were the most abundant species in woodlands (Table 1). These species also were quite common in the woodlandprairie edge, especially Yellow Warbler. Less common were Veery and Ovenbird, which occupied the most mature woodland stands in deep, broad coulees and along some eastfacing slopes. Red-Eyed Vireo was most frequently found in such places, but occurred occasionally in woodland-prairie edge. Gray Catbird, Cedar Waxwing, and Spotted 
Towhee generally occurred near edges of relatively young woodland stands, usually in understory shrub especially Chokecherry.

\section{Woodland-Prairie Edge Species}

Woodland-prairie edge was the most important habitat of Willow Flycatcher, Song Sparrow, and Brown-headed Cowbird (Table 1). Because many of our detections of Brown-headed Cowbird consisted of single adults of either sex, the species' abundance in edge and open habitats seemed better reflected by its frequency of occurrence: we detected cowbirds on about $40 \%$ of survey plots on the woodland-prairie edge (Figure 3 ), compared with only $3-18 \%$ of plots in more open habitats. Song Sparrow typically occupied edge habitat at the bottom of slopes, near water. Willow Flycatcher occurred mainly in extensive tall shrub up to the midslope.

\section{Grassland Species}

Clay-colored Sparrow was the only species that was common in all upland habitats on DLNWR; it was as abundant in woodlandprairie edge, where tall shrub cover was extensive, as it was in drift prairie where tall shrubs were less prevalent (Table 1, Figure 3). Other grassland bird species occurred in drift prairie, prairie slope, and dense nesting cover habitats. Savannah Sparrow was particularly ubiquitous in drift prairie and dense nesting cover and appeared to avoid woodland edge. Bobolink was common in drift prairie and in dense nesting cover especially where hay had been harvested 1-3 years earlier. Vesper Sparrow and Grasshopper Sparrow were less common than Clay-colored and Savannah sparrows, preferring prairie slope. Sprague's Pipit occurred along several upper prairie slopes and in drift prairie areas that had been prescribe-burned and grazed during the previous 4-5 years. Most detections of the infrequently occurring Baird's Sparrow also were in recently burned and grazed drift prairie. Western Meadowlark was recorded only occasionally, in drift prairie or dense nesting cover. Horned Lark and Killdeer occurred rarely, on recently ( $<6$ months) prescribe-burned drift prairie. Dense nesting cover was important habitat for Sedge Wren and Le Conte's Sparrow (Table 1).

\section{Discussion}

We found that contemporary upland habitats at DLNWR support a varied breeding bird community: 72 upland breeding species, with 5 to 14 species common in each of five major upland habitats. The total number of breeding bird species on the refuge may be nearly twice as great, however, when considering rare to occasional species in uplands in addition to those closely associated with buildings on and adjacent to the refuge (e.g., House Sparrow, Barn Swallow), plus many species of grebes, terns, ducks, rails, and other waterbirds that breed in the marshes and open water impoundments. Although a list of bird species specific to DLNWR has not been compiled since the 1960s, a collective list of birds species occurring on DLNWR and nearby Upper Souris and J. Clark Salyer National Wildlife Refuges indicates that 150 species "nest regularly" on the three refuges. ${ }^{1}$

\section{Between-year Differences}

Occurrences of several common bird species differed between our 1994 and 2001 surveys. Increased occurrences of common grassland species - Clay-colored Sparrow, Savannah Sparrow, and Bobolink - likely were associated with concurrent increases in local or regional populations. Average total numbers of these three species increased by 2- to 4fold on Breeding Bird Survey routes within $100 \mathrm{~km}$ of DLNWR between 1994 and $2001 .^{14}$ These increases may be linked to increased growth of grassland vegetation from above-average annual precipitation during the period 1994-2000. The attractiveness of native prairie on DLNWR to grassland birds also may have improved due to a general increase in the ratio of herbaceous to woody vegetation as a result of prescribed burns, at least for Bobolink and perhaps Savannah Sparrow. ${ }^{12}$ Clay-colored Sparrow abundance typically declines following burning of northern mixed-grass prairie. ${ }^{9,12}$ 

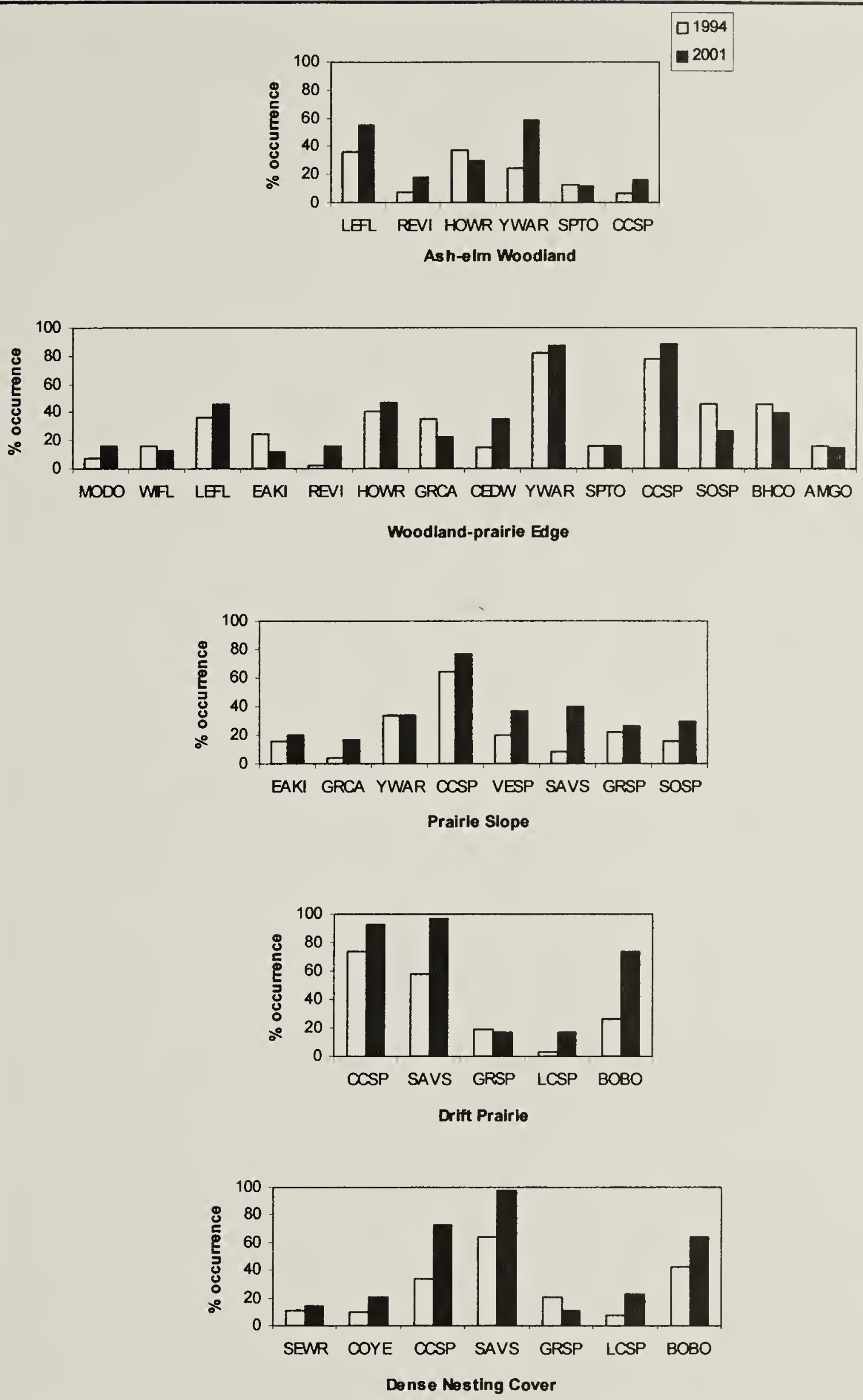

Figure 3. Frequency of occurrence of common breeding bird species in major upland habitats at Des Lacs National Wildlife Refuge, 1994 (wlite bars) and 2001 (dark bars). Species include American Goldfinch (AMGO), Brown-lueaded Cowbird (BHCO), Bobolink (BOBO), Clay-colored Sparrow (CCSP), Cedar Waxwing (CEDW), Common Yellowthroat (COYE), Eastern Kingbird (EAKI), Gray Catbird (GRCA), Grasshopper Sparrow (GRSP), House Wren (HOWR), Le Conte's Sparrow (LCSP), Least Flycatcher (LEFL), Mourning Dove (MODO), Red-eyed Vireo (REVI), Savanuali Sparrow (SAVS), Sedge Wren (SEWR), Song Sparrow (SOSP), Spotted Towlee (SPTO), Vesper Sparrow (VESP), Willow Flycatcher (WIFL), Yellow Warbler (YEWA). 
Breeding birds and habitat: present and past

Most woodland bird species and many woodland-prairie edge bird species that we found probably were rare or absent as breeding species when trees were scarce in the area a century ago, ${ }^{7}$ for example: Cooper's Hawk, Hairy Woodpecker, Least Flycatcher, Red-Eyed Vireo, Veery, American Crow, and Baltimore Oriole. Perhaps even Brown-headed Cowbird was much less common in the area before settlement; we found it to be less common in open habitats compared to woodlandprairie edge. In addition, several introduced species such as Ring-necked Pheasant now occur. Thus, species diversity presumably is greater now than it was before the area was settled by peoples of European descent in the late $1800 \mathrm{~s}$, and before establishment of the refuge in 1935 .

In contrast, the diversity of grasslanddependent bird species has diminished on DLNWR. Although we found several grassland bird species to be quite common (Clay-colored Sparrow, Savannah Sparrow, and Bobolink), most were uncommon and some were absent. Killdeer, Horned Lark, Western Meadowlark, Sprague's Pipit, and Baird's Sparrow are among breeding species considered characteristic of the area's mixedgrass prairie, ${ }^{5,15}$ but they occur infrequently on DLNWR. Chestnut-collared Longspur, another characteristic species, was not detected on DLNWR although we observed it defending breeding territories on adjacent, privately owned tracts of grazed prairie. Burrowing Owl and Ferruginous Hawk also are characteristic, but were not observed during our study and have not been recorded on DLNWR for decades. The community of grassland bird species that are uncommon to absent on DLNWR generally requires shorter, sparser, more herbaceous prairie vegetation than that available on the refuge today. ${ }^{11}$ Replacement of native grasses by introduced species, especially Smooth Brome, also reduces the attractiveness of the mixed-grass prairie for several native passerines especially the endemic Baird's Sparrow and Sprague's Pipit. ${ }^{13}$ Increases in judicious use of prescribed burning and livestock grazing would provide more suitable habitat for these native species, while still providing habitat for more generalized grassland bird species such as Savannah Sparrow and Clay-colored Sparrow. ${ }^{12}$ Regardless of vegetation conditions, some species such as Northern Harrier may avoid narrow tracts of drift prairie bordered by cropland, simply because they need broader grassland tracts; ${ }^{10}$ territories of the harrier may cover 100-200 ha. ${ }^{2}$ Western Meadowlark has relatively large territories (5-10 ha) for a grassland passerine, but evidence of the species' sensitivity to habitat area is unclear in the northern Great Plains. ${ }^{10}$

\section{Implications for managing habitat}

Eleven grassland bird species that occurred at DLNWR during or prior to our survey are included in a 1995 FWS list of "Nongame Birds of Management Concern" (Table 1). ${ }^{16}$ Only one woodland species (Veery) and none of the woodland-prairie edge species that we recorded at DLNWR are on the list. Woodland-prairie edge is a widespread habitat type on the refuge that, in the absence of fire, would continue to replace drift prairie and some prairie slope. The only grassland bird species that were common in this habitat were Clay-Colored Sparrow and Brown-headed Cowbird. Woodland bird species that were common in the woodland-prairie edge - Least Flycatcher, House Wren, and Yellow Warbler - are widespread in North America and have stable to increasing populations. ${ }^{14}$ Conversion of woodland-prairie edge habitat to drift prairie at DLNWR, through repeated prescribed fire, would negligibly influence continental population trends of woodland bird species while clearly benefitting populations of grassland bird species, which generally are declining. Conversely, mature ash-elm woodland at DLNWR typically occurs in steep, fire-sheltered areas that may be 
overwhelmingly difficult to restore to prairie. Such areas probably would continue to provide modest habitat for area-sensitive, "forest interior" species such as Veery and Ovenbird without hindering widespread improvement in grassland bird habitat. ${ }^{6}$

Dense nesting cover was planted on DLNWR mainly to provide nesting cover for upland-nesting ducks, but we found that it also increased grassland bird diversity on the refuge by providing important habitat for Sedge Wren and Le Conte's Sparrow. We also detected several Nelson's Sharp-tailed Sparrows in dense nesting cover. These three species typically are associated with wetland margins in the northern plains region, but the rank, coarse cover of introduced grassforb stands apparently emulates the native wet meadow vegetation that attracts these species. " We also often observed Northern Harriers and Short-eared Owls foraging in dense nesting cover; nesting by these species has been noted in dense nesting cover at DLNWR (FWS, unpubl. data).

\section{Conclusions}

We documented a varied upland breeding bird community at DLNWR, but one in which native grassland bird diversity has declined. Conservation needs of these grassland bird species are urgent. The total area available on many of the refuge's drift prairie tracts may be inadequate for some species. Suitable habitat could be made widely available for other grassland bird species, however, with moderately aggressive land management, especially expanded use of a combined fire and grazing regime that was beginning to develop at DLNWR during our study. Efforts to improve grassland bird habitat on the refuge coincide with restoration goals for native prairie flora, as might be the case in other prairie river valleys of the northern plains region.

\section{Acknowledgments}

We dedicate this paper to the memory of Bob and Ann Gammell, amateur naturalists who contributed greatly to the knowledge and appreciation of birdlife in northwestern North Dakota. Beth Madden provided sound advice on our survey methods. Sharon Anderson and Natalie Fahler helped summarize data. We thank Steve Davis, Todd Grant, Ron Martin, Cory Rubin, Dan Severson, and Karen Smith for helpful discussions and comments surrounding this paper.

1. BERKEY, G., and R. MARTIN. 2001. National Wildlife Refuges along the Souris River Loop: bird list. U.S. Fish and Wildlife Service: Des Lacs, J. Clark, and Upper Souris National Wildlife Refuges, North Dakota.

2. BILDSTEIN, K. L., and J. B. GOLLOP. 1988. Northern Harrier Circus cyaneus. In: Palmer, R. S. (ed.). The Birds of North America, Vol. 4. Yale University Press, New Haven, Connecticut. p. 251-303.

3. BLUEMLE, J. P. 1991. The face of North Dakota. North Dakota Geological Survey Educational Series 21.

4. CAMPBELL, C., I. D. CAMPBELL, C. B. BLYTH, and J. H. MCANDREWS. 1994. Bison extirpation may have caused aspen expansion in western Canada. Ecography 17:360-362.

5. COUES, E. 1878. Field notes on birds observed in Dakota and Montana along the forty-ninth parallel during the seasons of 1873 and 1874. U.S. Geological and Geographic Survey Territorial Bulletin 4:545661.

6. GRANT, T. A., and G. B. BERKEY. 1999. Forest area and avian diversity in fragmented aspen woodland of North Dakota. Wildlife Society Bulletin 27:904-914.

7. GRANT, T. A., R. K. MURPHY, R. DIEBOLL, and C. RUBIN. ms In Review. Increases in woody cover on prairie refuges in North Dakota. 


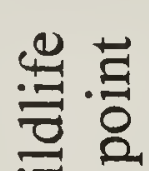

3 齐

ㅈ.

.

乙造

of 2 드

ช

थ

คั ర్ల.

4 苋䒕

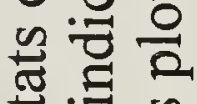

䒕范

글

현.

家这

응

夏

$\Xi$ 물

过

运.

형 额

on 0

든

응

额

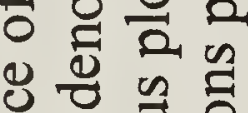

政

푱

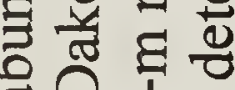

क

施

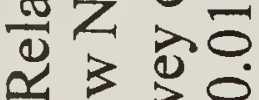

4.

的要

急

ब

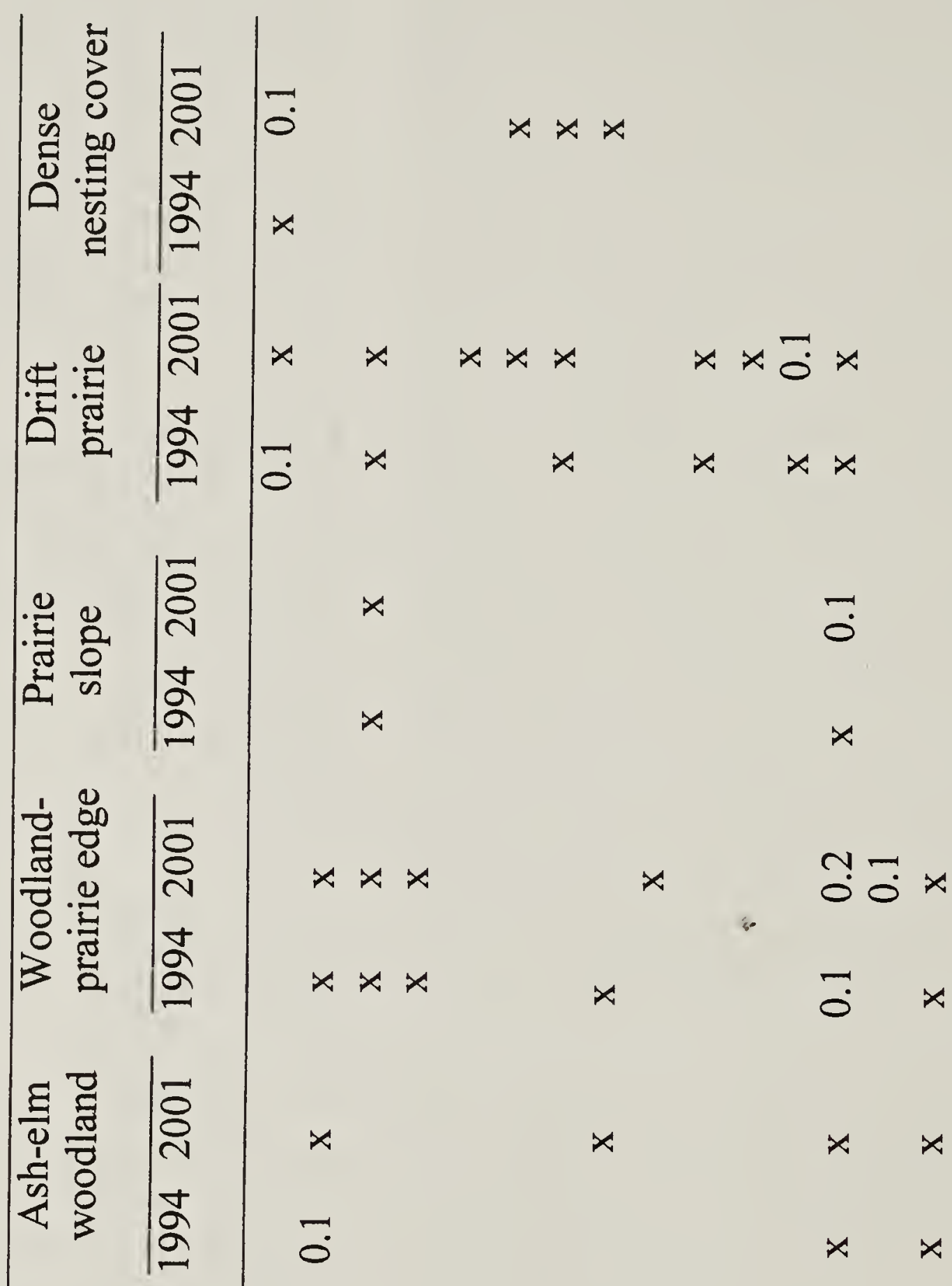




$$
\begin{aligned}
& \text { 3. } \\
& x \quad x \quad x \quad \overrightarrow{0} \\
& \ddot{0} \quad x \quad x \\
& x \quad x \quad \overrightarrow{0} \quad x \quad x \\
& \overrightarrow{0} \overrightarrow{0} \stackrel{1}{0} \\
& x \times x \stackrel{0}{0} \\
& \ddot{0}
\end{aligned}
$$

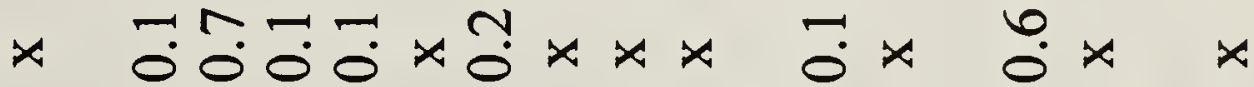

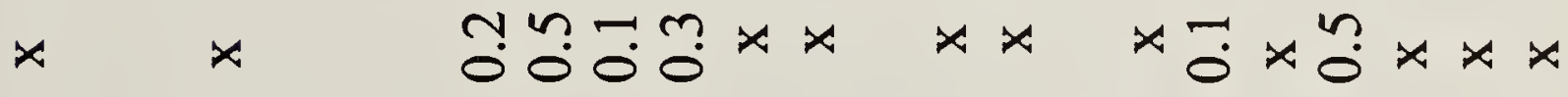

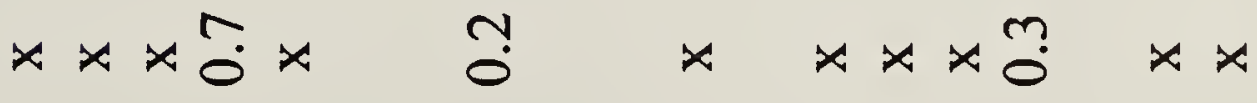

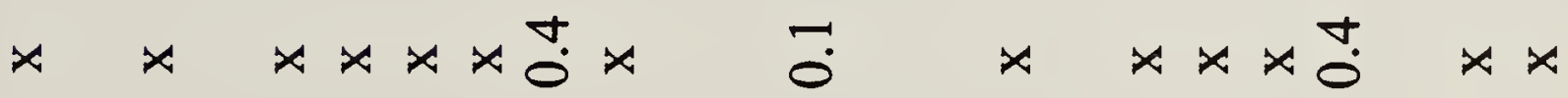

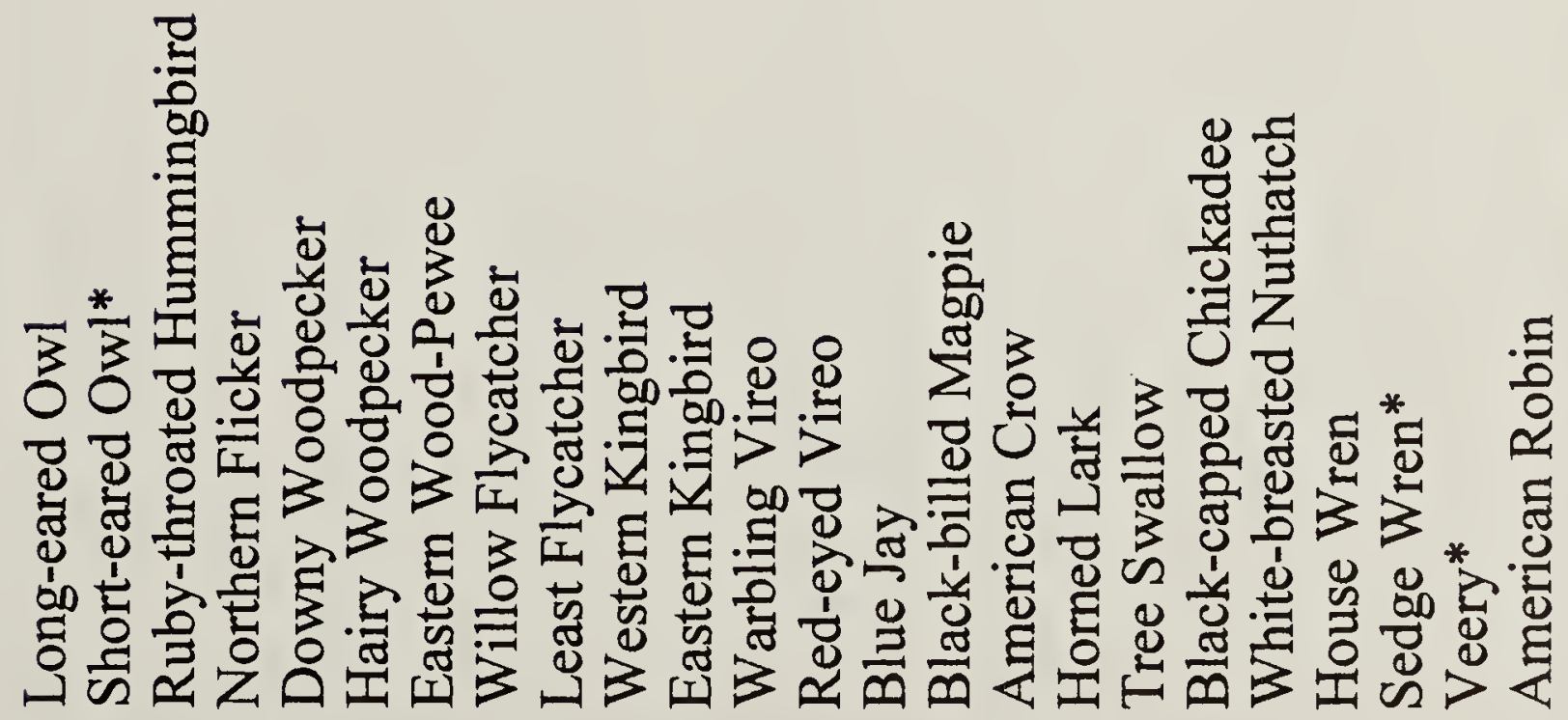




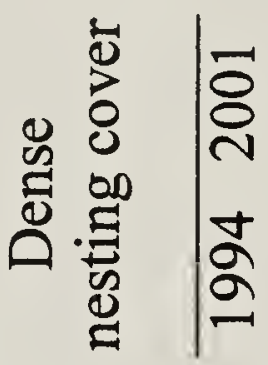

$-\frac{\pi}{2} \cdot \frac{\pi}{3}$

要

竞

:

竎

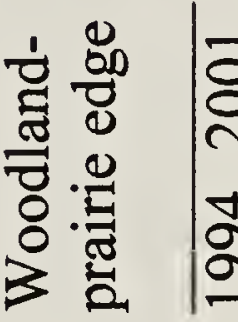

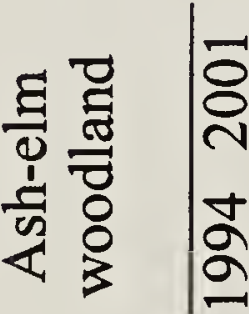

$\overline{0} \times \overrightarrow{0}$

$\times x \quad \overrightarrow{0} \times \overrightarrow{0}$

×تே

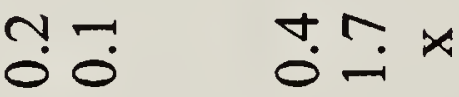

$x$

$x$

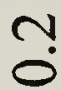

$\stackrel{\sim}{i}$

ֻั

$\because \times 0$ ?

$\overline{0} \times \stackrel{n}{i} \times \infty$

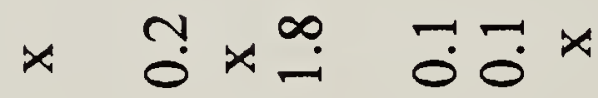

$\overrightarrow{0} \overrightarrow{0} \times \times$ N்ָ

$\ddot{0} \ddot{0} x \times x$

$\ddot{0}$

$$
30 x \times x
$$

กู

$\frac{\overline{0}}{30}$

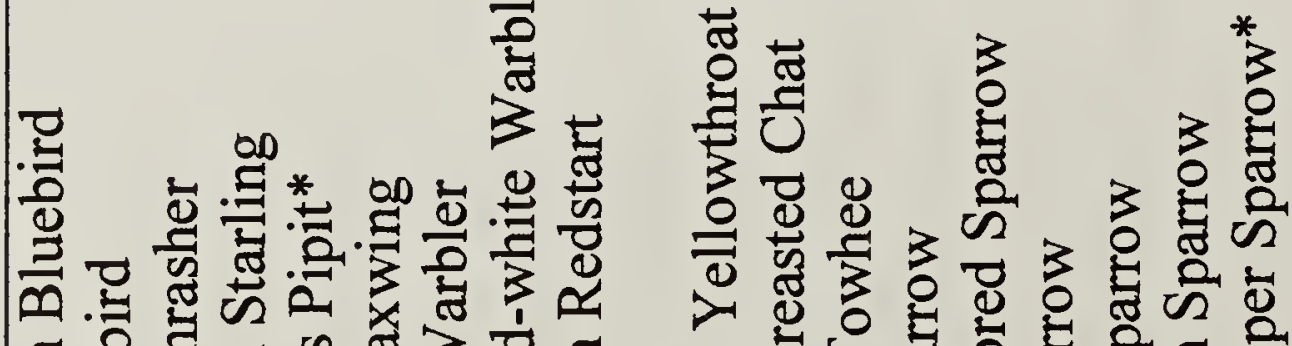

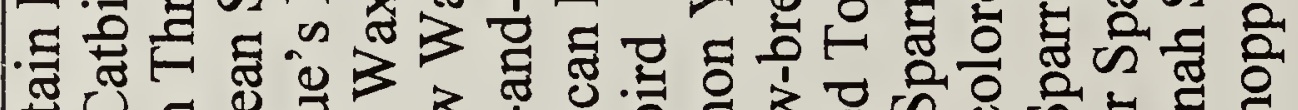

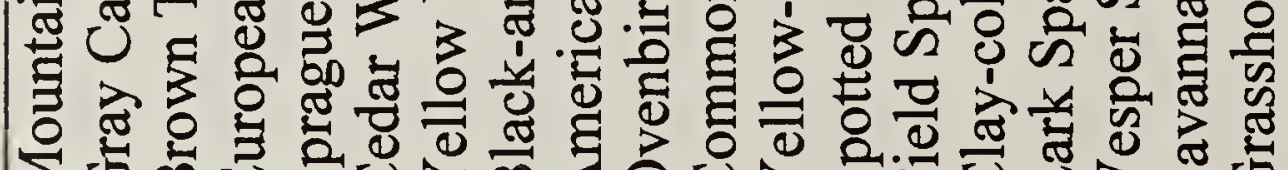

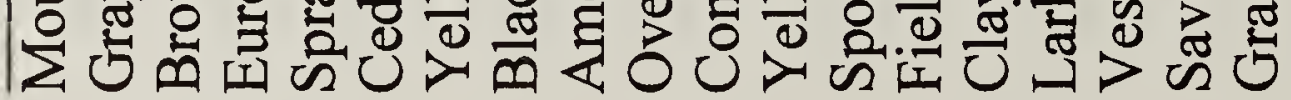




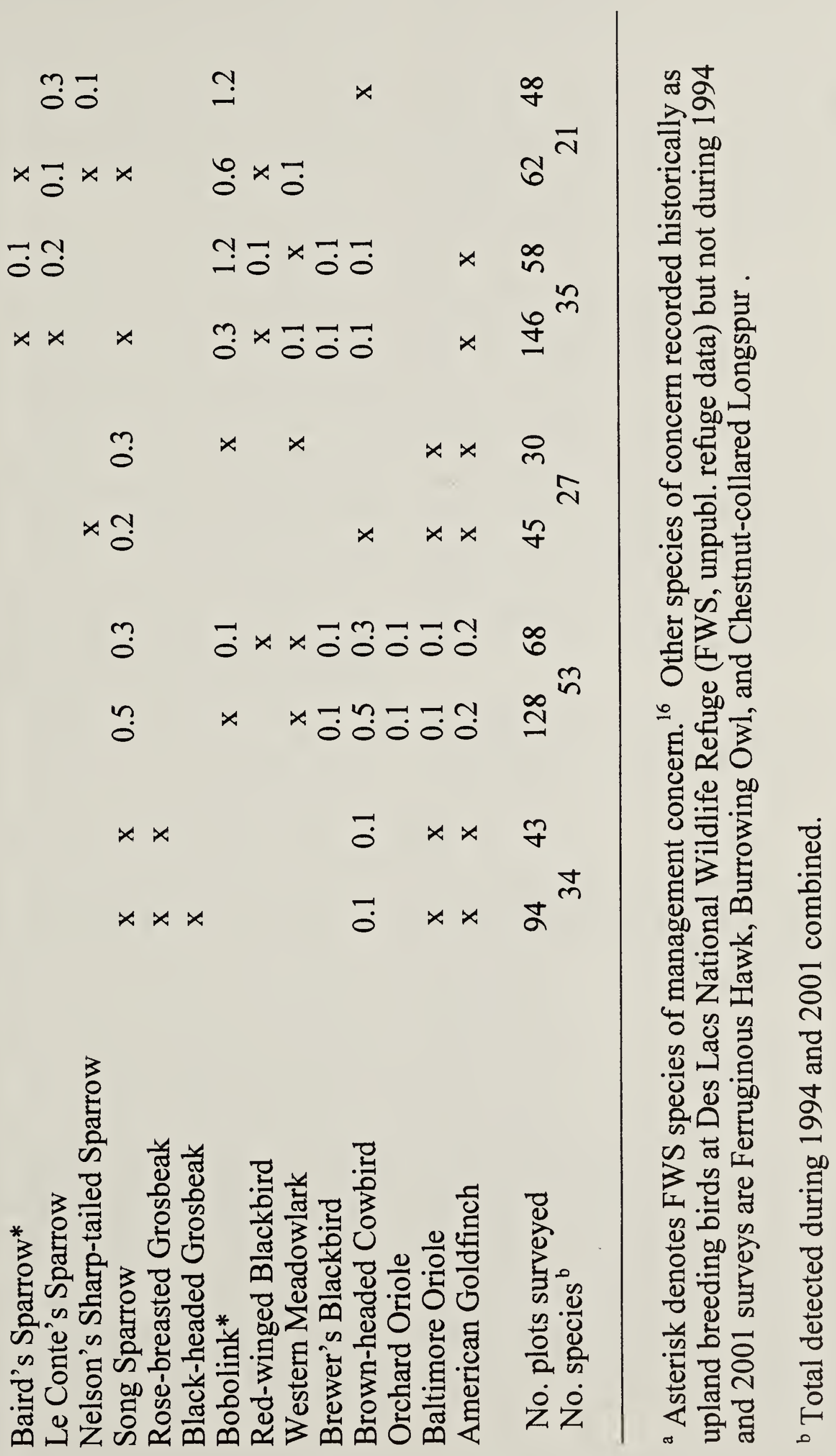


8. HUTTO, R. L., S. M. PLETSCHET, and P. HENDRICKS. 1986. A fixed-radius point count method for nonbreeding and breeding season use. Auk 103:593-602.

9. JOHNSON, D. H. 1996. Effects of fire on bird populations in mixed-grass prairie. In: Knopf, F. L. and F. B. Samson (eds.). Ecology and Conservation of Great Plains Vertebrates. Springer, New York. p. 181-206.

10. JOHNSON, D. H., and L. D. IGL. 2001. Area requirements of grassland birds: a regional perspective. Auk 118:24-34.

11. JOHNSON, D. H., L. D. IGL, J. A. DECHANT, C. M. GOLDADE, M. L. SONDREAL, B. R. EULISS, and A. L. ZIMMERMAN. 1999. Effects of Management Practices on Grassland Birds. U.S. Geological Survey, Biological Resources Division-Northern Prairie Wildlife Research Center, Jamestown, North Dakota.

12. MADDEN, E. M., A. J. HANSEN, and R. K. MURPHY. 1999. Influence of prescribed fire history on habitat and abundance of passerine birds in northern mixed-grass prairie. Canadian FieldNaturalist 113:627-640.

13. MADDEN, E. M., R. K. MURPHY, A. J. HANSEN, and L. MURRAY. 2000. Models for guiding management of prairie bird habitat in northwestern North Dakota. American Midland Naturalist 144:377-392.

14. SAUER, J. R., J. E. HINES, and J. FALLON. 2001. The North American Breeding Bird Survey, Results and Analysis 1966 - 2001. Version 2001 .2, USGS Patuxent Wildlife Research Center, Laurel, Maryland.

15. STEWART, R. E. 1975. Breeding birds of North Dakota. Tri-college Center for Environmental Studies, Fargo, North Dakota.

16. U.S. FISH AND WILDLIFE SERVICE. 1995. Migratory nongame birds of management concern in the United States: the 1995 list. U.S. Fish and Wildlife Service, Office of Migratory Bird Management, Washington, D.C.

\section{RURAL BANDERS IN THE YORKTON AREA*}

\section{STUART HOUSTON, 863 University Drive, Saskatoon, SK S7N 0J8}

Of the six early banders active within the Yorkton - Duck Mountain (YDM) bird area, Judge J.A.M. Patrick, who banded from 1929 to 1933 , was the first. ${ }^{2}$ In 1937, Bill and Lindsay Wotherspoon banded 885 birds of 42 species, with 12 recoveries, in the village of Hyas and on their farm on the north side of that village." Three "outside" banders visited the YDM area in the 1940s: Fred
Bard, of the Saskatchewan Natural History Museum, released 11 banded magpies and 13 crows as part of his crow and magpie campaign. ${ }^{3}$ R. Lorne Scott banded 19 Great Horned Owls, 19 Red-tailed Hawks, 6 Blackbilled Magpies, 756 Tree Swallows and 425 Mountain Bluebirds along his bird box trail on Highway 35 , within the western boundary of the YDM area. ${ }^{4}$ J.A. Briggs of Regina 